\title{
Performance of an Anode Supported Solid Oxide fuel cell with Indirect Internal Reforming
}

\author{
S. T. Park, J. Zou, H. C. Yoon, N. M. Sammes and J. S. Chung \\ Department of Chemical Engineering, Pohang University of Science and Technology, \\ San 31, Hyoja-Dong, Nam-Gu, Pohang, 790-784, Republic of Korea
}

The conversion of fuel into hydrogen-rich gas is necessary for fuel cells. This can be achieved either indirectly in fuel processing systems, in which the hydrocarbon feed is converted in an external catalytic steam reformer, or directly in the fuel cell. In this paper, the unit module of solid oxide fuel cell was assembled by one reformer and four cells. The reformer was fabricated by extruded dummy cell and combined with two cells on each side respectively. The reforming catalyst was coated on internal channel of the dummy cell. The unit module has successfully tested with wet $\mathrm{CH}_{4}$ as fuel and air as oxidant and its maximum power density exceeded $150 \mathrm{~mW} / \mathrm{cm}^{2}$ at $750^{\circ} \mathrm{C}$.

\section{Introduction}

The solid oxide fuel cells offer a clean technology to electrochemically generate electricity with high conversion efficiency. Also natural gas can be reformed within the cell because of their high operation temperature $\left(1000^{\circ} \mathrm{C}\right)$. This paper describes the concept and trial results of an anode supported solid oxide fuel cell with indirect internal reforming module system. This concept is based on the extruded flat tubular anode support. On the outside surface of the support there are engraved channels in a horizontal direction which are for air; and inside of the support there are channels for fuel. Figure 1 shows a photograph of the unit-module, where the catalyst coated reformer is placed center with four-cells. $\mathrm{CH}_{4}$ is passed up the center.

\section{Results and Discussion}

The anode support was fabricated by extrusion with width of $20 \mathrm{~mm}$ and length of 200 $\mathrm{mm}$. The support was ground after calcining at $1100^{\circ} \mathrm{C}$ and porosity is controlled using pore formers. And then anode functional layer and YSZ layer were coated on pre-sintered support using dip coating and co-sintered at $1400^{\circ} \mathrm{C}$. GDC and LSCF(Cathode) were prepared by spray coating and sintered at $1200^{\circ} \mathrm{C}$. Dummy cell is fabricated with same process to YSZ coating step. Prepared Ni catalyst was coated using slurry into internal channel of support. All cells are arrayed as Figure 1 and Au wire, Pt mesh was attached on cathode layer and Ag interconnect layer as current collector.

Figure 1 shows a photograph of the unit-module, where the catalyst coated reformer is placed center with four-cells. $\mathrm{CH}_{4}$ passed up the center and separate into each cells by reformed gas through a designed jig. 
Figure 2 shows the performance of the unit-module at various temperatures. It has promising performance of $152 \mathrm{~mW} / \mathrm{cm}^{2}$ at $750^{\circ} \mathrm{C}$ with active cell area as $80 \mathrm{~cm}^{2}$. As a result, we obtained the power of $12.1 \mathrm{~W}$ using $\mathrm{CH}_{4}$.

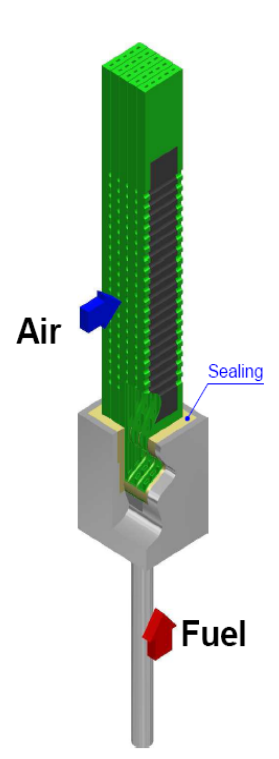

(a)

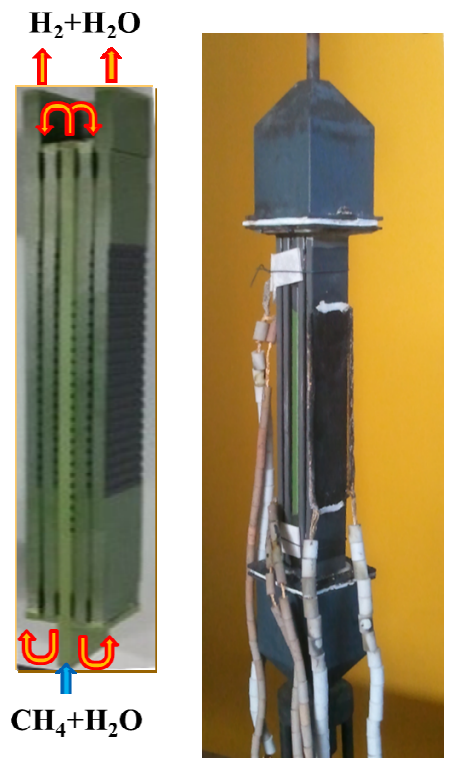

(b)

Figure 1. (a) Schematic diagram and photograph for monolithic indirect internal reforming unit module before performance test; (b) Photograph of the unit-module after performance test.
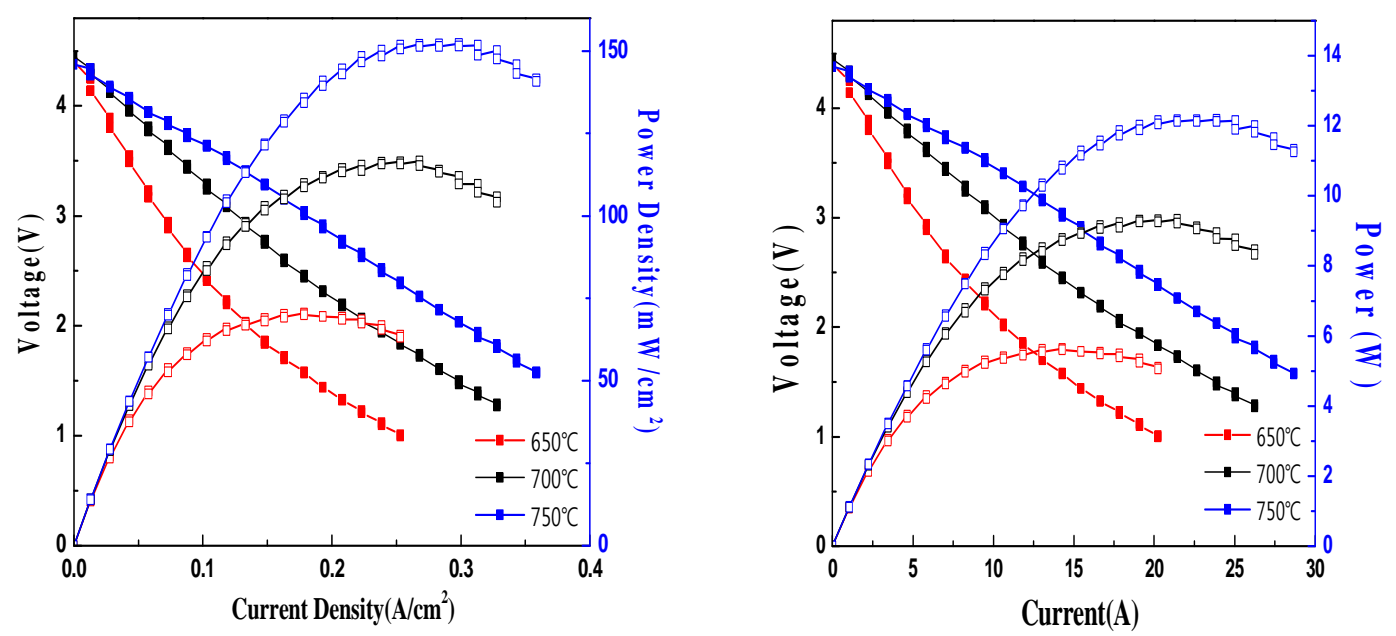

Figure 2. Performance of the SOFC unit-module tested at steam/carbon $=2$.

\section{Conclusion}

We have successfully demonstrated that electrical power generation can be achieved through the indirect internal reforming using $\mathrm{CH}_{4}$. The unit-module consisted 4-cells and 
1-reformer. The module generates a maximum power of $12 \mathrm{~W}$ at $750^{\circ} \mathrm{C}$. This means the indirect internal reforming SOFC module will be the most promising type.

\section{Acknowledgments}

This work was supported by the National Research Foundation of Korea (NRF) grant funded by the Korea government (MEST) (No. 2012R1A2A2A03047613).

\section{References}

1. S. C. Singhal, Solid-State Ionics, 135, 305-313 (2000).

2. J. H. Kim, R. H. Song, K. S. Song, S H. Hyun, D. R. Shin and H. Yokokawa, J. Power Sources, 122(2), 23 (2003).

3. E. Gaura and R. M. Newman, ECS Trans., 4(1), 3 (2006). 